\title{
DELAYED FACIAL PALSY - AN UNCOMMON COMPLICATION OF TYMPANOMASTOIDECTOMY
}

Shoba $\mathrm{K}^{1}$, Srinivasan $\mathrm{K}^{2}$, Deepak Raj ${ }^{3}$, Hari Kumar ${ }^{4}$

\section{HOW TO CITE THIS ARTICLE:}

Shoba K, Srinivasan K, Deepak Raj, Hari Kumar. "Delayed Facial Palsy - An Uncommon Complication of Tympanomastoidectomy". Journal of Evolution of Medical and Dental Sciences 2014; Vol. 3, Issue 04, January 27; Page: 824-826, DOI: 10.14260/jemds/2014/1910

ABSTRACT: Facial nerve palsy after ear surgery is a troublesome postoperative complication for both patient and the surgeon. Though most of the palsies occur in the immediate post-operative period, in rare instances patients may develop facial nerve palsy anywhere from several hours to several days after ear surgery. We hereby present a case of delayed facial nerve palsy, after 5 days following surgery, in 48 year old women operated for tubotympanic type of chronic suppurative otitis media. Patient recovered well with oral steroid therapy. Delayed facial nerve palsy is a very rare complication of ear surgery. Reactivation of virus is the probable etiology.

KEY WORDS: Facial nerve palsy, Delayed, Tympanomastoidectomy.

INTRODUCTION: Facial nerve palsy is troublesome post-operative complication for both the patient and the surgeon. Delayed facial nerve palsy is a rare complication of ear surgeries. It is reported only after tympano-mastoidectomy, stapes surgery, cochlear implant and endolymphatic surgery. However it is not reported after myringoplasty or myringotomy. Herein, we report a case of delayed facial nerve palsy after tympano-mastoidectomy.

CASE REPORT: A 48 year old female patient presented to ENT outpatient department with copious, non-foul smelling mucopurulent ear discharge and decreased hearing in the left ear for the past 10 years. On examination she had a moderate sized central perforation. We planned tympanomastoidectomy as discharge was copious. Patient underwent a simple mastoidectomy. Aditus was made patent. Type- 1 tympanoplasty was done by underlay technique. In the immediate post-operative period patient was fine. On the $5^{\text {th }}$ postoperative day patient developed grade- 3 facial nerve palsy. Steroids and physiotherapy were started. Patient improved over a period of 2 weeks. Graft take up was good.

DISCUSSION: Delayed facial palsy is the one which occurs after otology and neurological surgeries in a delayed fashion. It is commonly seen after acoustic neuroma surgeries (2.2-29\%) ${ }^{1}$. It has also been described after vestibular neurectomy $(0-18 \%)^{1}$, stapes surgery $(0.5-1 \%)^{1}$, endolymphatic sac surgery $(1 \%)^{1}$, cochlear implantation surgery $(0.4-0.7 \%)^{1}$ and mastoidectomy $(0.38-1.4 \%)^{1}$.

If stress is expected to be the cause for delayed facial palsy as with Bell's palsy, all types of major surgical procedures could produce this. But delayed facial palsy is seen only in patients who undergo otological and neurological surgeries. All ear surgeries, except for endolymphatic sac procedures, exposed the chorda tympani, and all surgeries, except for stapedectomy/stapedotomy, underwent drilling of mastoid. Hence the two important surgical procedures probably causing the delayed facial palsy are the 'mastoidectomy procedure' and 'facial nerve and/or chorda tympani nerve exposure'2. Furthermore, delayed facial palsy was always observed on the same side as the 
operated ear. Therefore, there is a strong relationship between delayed facial palsy and the ear surgeries ${ }^{3}$. It can occur up to two weeks after ear surgery.

Review of literature showed many causes of facial nerve palsy.

1. Reversible delayed facial paralysis is usually due to compression of nerve fibers by edema, damage to blood supply to facial nerve during surgery 4 , drilling induced heat or inflammation in the early post-operative period 5,6 .

2. Late post-operative delayed facial nerve palsy could be due to viral reactivation. Exposure of facial nerve / chorda tympani, thermal or mechanical manipulation around facial nerve or steroid / antibiotics soaked gel foam around geniculate ganglion can cause herpes virus reactivation ${ }^{2}$. Varicella zoster virus is the most probable etiology ${ }^{7}$. This complication is more in patients with a history of viral reactivation.

3. Allergy to BIPP pack can cause progressive delayed facial nerve palsy8.

4. Post-operative infection could cause delayed facial palsy.

Serological test can confirm viral reactivation in some patients. Gadolinium enhancement of the labyrinthine portion of the facial nerve is recorded in MRI in a few studies 9.

Prognosis is generally good if the palsy does not progress to complete paralysis. Patients with complete paralysis have a more variable prognosis, which ranges from normal function to permanent total paralysis. This could be due to edema around facial nerve due to surgery. Steroids are the important first line management for this condition. Intra-operative decompression of the meatal foramen has been used with some success in a few studies ${ }^{10}$. Acyclovir has been advised by a few ${ }^{11}$.

Acyclovir can be given for patients with history of viral activation as prophylaxis to delayed facial palsy ${ }^{12}$.

CONCLUSION: Delayed facial nerve palsy is a rare complication of ear surgery. Recovery rate is very high.

\section{REFERENCES:}

1. Gantz BJ, Gubbels SP, Samy RN. Surgery of facial nerve. In: Gulia AJ, Minor LB, Poe DS. GlasscorkShambaugh Surgery of the ear. People's Medical Publishing House-USA. 2010, $6^{\text {th }}$ ed; 619-642.

2. Kamakura T, Kitahara T, Horii A, Inohara H. Delayed facial nerve palsy after endolymphatic sac surgery. Int.Adv.Otol.2011; 7(1): 130-133.

3. Kitahara T, Kubo T, Doi K, Mishiro Y, Kondoh K, Horii A, Okumura S, Miyahara H. Delayed facial nerve palsy after otologic surgery. Nihon Jibiinkoka Gakkai Kaiho. 2006 Jul; 109(7):600-5.

4. Tu TY. Cholesteatoma surgery in pneumatised and non-pneumatised temporal bones. J Chin Med Assoc 2005 Oct; 68(10): 458-62.

5. Lalwani AK, Butt FY, Jackler RK. Delayed onset facial nerve dysfunction following acoustic neuroma surgery. Am J Otol 1995; 16:758-764.

6. Abbas GM, Jones RO. Measurements of drill- induced temperature changes in the facial nerve during mastoid surgery. A cadaveric model using diamond burs. Ann Otol Rhinol Laryngol 2001;110:867-870.

7. Vrabec JT. Delayed facial palsy after tympanomastoid surgery. Am J Otol 1999;20:26-30. 
8. Das AK, Sabarigirish K, Kashyap RC. Facial nerve paralysis: A three year retrospective study. Indian J Otolaryngol Head Neck Surg 2006 July; 58(3): 225-228.

9. Cohen M, Kirsch C, Mendelsohn A, Ishiyama A. MRI Findings in Delayed Facial Palsy after Stapedectomy. Otolaryngol Head Neck Surg August 2008; 139 (2): 152.

10. Gianoli GJ, Kartush JM. Delayed facial palsy after acoustic neuroma resection: the role of viral reactivation. Am J Otol. 1996 Jul;17(4):625-9.

11. Magliulo G, D'Amico R, Di Cello P. Delayed facial palsy after vestibular schwannoma resection: clinical data and prognosis. J Otolaryngol. 2003 Dec;32(6):400-4.

12. Gianoli GJ, Kartush JM. Delayed facial palsy after acoustic neuroma resection: the role of viral reactivation. Am J Otol. 1996 Jul;17(4):625-9.

\section{AUTHORS:}

1. Shoba K.

2. Srinivasan K.

3. Deepak Raj

4. Hari Kumar

\section{PARTICULARS OF CONTRIBUTORS:}

1. Associate Professor, Department of E.N.T, Saveetha Medical College, Thandalum, Kancheepuram.

2. Professor and HOD, Department of E.N.T, Saveetha Medical College, Thandalum, Kancheepuram.

3. Senior Resident, Department of E.N.T, Saveetha Medical College, Thandalum, Kancheepuram.
4. Assistant Professor, Department of E.N.T, Saveetha Medical College, Thandalum, Kancheepuram.

\section{NAME ADDRESS EMAIL ID OF THE CORRESPONDING AUTHOR:}

Dr. K. Shoba,

Shanthi Health Center,

Opp. To Sengalamman Koil,

Sholavarum - 600067.

E-mail: shobasridhar@ymail.com

Date of Submission: 08/01/2014.

Date of Peer Review: 09/01/2014.

Date of Acceptance: 17/01/2014.

Date of Publishing: 21/01/2014. 